\title{
Evaluation of Antimicrobial Activity of Various Chemicals on Isolated Chicken and Mutton Spoilage Microorganisms
}

\section{Bilal Ahmad Mir ${ }^{1 *}$, Amin Mir ${ }^{2}$, Dhyal Singh ${ }^{1}$ and Zainab Rao ${ }^{1}$}

${ }^{1}$ Department of Microbiology and Zoology, Uttarakhand PG College of Biomedical Sciences and Hospital, Dehradun, India

${ }^{2}$ Research Scholar at Uttarakhand Technical University, Dehradun, India

\begin{abstract}
The study was carried out on the isolation of various micro-organisms, in which various samples of chicken and mutton were collected from different locations of the Dehradun. The process of slaughtering of the chicken and mutton as per the survey was of two types- viz, Jatka and Halal. The isolated micro-organisms from the chicken samples of Jatka type include- Vibrio, Enterobacter species, Clostridium, E. coli, Shigella, whereas the micro-organisms isolated from the chicken samples of Halal type include only Enterobacter species, Clostridium and E. coli. The micro-organisms isolated from the mutton sample of Jatka type include, Shigella, E. coli, Vibrio, Staphylococcus, and the micro-organisms isolated from the mutton samples of Halal type include only $E$. coli, Vibrio and Staphylococcus. The micro-organisms have been isolated and identified by various biochemical tests. The isolated micro-organisms have been then testified for antimicrobial susceptibility test against various chemical substances which include, Gentamicin, Naphthazarin, Azithromycin, Citric Acid, Amphotericin-B, Clindomycin, Cefixime, Norfloxacin, Streptomycin, Ampicilin. Among the various used chemical substances, Gentamicin have been found effective in inhabiting the growth of all the isolated micro-organisms, followed by Norfloxacin, Streptomycin, Ampicilin, Azithromycin, Citric Acid. Least antimicrobial activity was observed for Naphthazarin, Amphotericin-B, Clindomycin, and Cefixime. Among the isolated micro-organisms shigella species was found to be less proned against the applied anti-microbial drugs, and the most susceptible micro-organism among the isolated micro-organisms includes E. coli. Also from the collected chicken and mutton samples the samples of Halal type have been to be less effective against the growth of micro-organisms as compared to the Jatka type samples, which could be due to different procedure of slaughtering technique.
\end{abstract}

Keywords: Chicken and mutton samples; Anti-microbial activity; Halal; Jatka; Vibrio; Enterobacter species; Clostridium; E. coli; Shigella; Staphylococcus

\section{Introduction}

Microorganisms can be used to transform raw foods into fermented delights, including yoghurt, cheese, sausages, Tempeh, pickles, wine, beers and other alcoholic products. On the other hand, foods also can act as a reservoir for disease transmission, and thus detection and control of pathogens and spoilage organisms are important areas of food microbiology. During the entire sequence of food handling from the producer to the final consumer, microorganisms can affect food quality and human health.

This study briefly summarizes current knowledge on the biological implications of biogenic amines on human health and collects data on the factors affecting their formation in meat and fermented meat products by Joanna et al. [1]. George-John et al. [2] studied on meat spoilage during distribution can be considered as an ecological phenomenon that encompasses the changes of the available substrata (e.g., low molecular compounds), during the prevailing of a particular microbial association, the so-called specific spoilage organisms (SSO).

Microbial contamination of poultry carcasses can be influenced by many factors during transport and slaughtering. The study carried out by Svobodová et al. [3] evaluated the impact of four processing steps (plucking, evisceration, washing and chilling) on the total viable counts (TVC), counts of Escherichia coli, Salmonella spp. and Listeria spp. incidence on broiler carcasses. Food borne illness is a major public health concern. The largest number of food borne illness cases attributed to poultry and poultry products are caused by paratyphoid serotypes of Salmonella and by Campylobacter jejuni as studied by White et al. [4]. Consumption of meat is continuously increasing worldwide. The annual per capita consumption increased from $10 \mathrm{~kg}$ in the 1960s to $26 \mathrm{~kg}$ in 2000 and will reach $37 \mathrm{~kg}$ by the year 2030 as per the reports by Stadnik et al. [5]. On the other hand, a significant portion of meat and meat products are spoiled every year. Kantor et al. reported that approximately 3.5 billion $\mathrm{kg}$ of poultry and meat were wasted at the consumer, retailer and foodservice levels which have a substantial economic and environmental impact.

\section{Material and Methods for Antimicrobial Analysis}

The antimicrobial analyses of various "Chicken and Mutton" samples were carried out at Uttarakhand College of Biomedical Sciences and Hospital, Dehradun. Microbial world is of great importance in the present world. They are beneficial in various ways to humans, not only they help to maintain the environment clean, but also they furnish various types of antibiotics which are useful against various diseases. So, this microbial analysis was carried out. All the chemicals used were of analytical grade. Different samples of chicken and mutton were collected from the local shops at DL Road and Sahastradhara Crossing, Dehradun then leaved all of these samples for 4 days for complete spoilage.

*Corresponding author: Bilal Ahmad Mir, Department of Microbiology and Zoology, Uttaranchal PG College of Biomedical Sciences and Hospital, Dehradun, India, Tel: +919897635334; E-mail: mohdaminir@gmail.com

Received May 22, 2017; Accepted May 27, 2017; Published May 31, 2017

Citation: Ahmad Mir B, Mir A, Singh D, Rao Z (2017) Evaluation of Antimicrobia Activity of Various Chemicals on Isolated Chicken and Mutton Spoilage Microorganisms. Med Chem (Los Angeles) 7: 900-903. doi: 10.4172/21610444.1000450

Copyright: @ 2017 Ahmad Mir B, et al. This is an open-access article distributed under the terms of the Creative Commons Attribution License, which permits unrestricted use, distribution, and reproduction in any medium, provided the original author and source are credited. 
Citation: Ahmad Mir B, Mir A, Singh D, Rao Z (2017) Evaluation of Antimicrobial Activity of Various Chemicals on Isolated Chicken and Mutton Spoilage Microorganisms. Med Chem (Los Angeles) 7: 900-903. doi: 10.4172/2161-0444.1000450

\section{Identification methods}

All the bacterial colonies were identified by Gram's staining method as they are Gram -ve or Gram +ve and several biochemical characterization methods. Litmus milk test, Gelatin Agar test and Urea agar media were used to determine the load of viable cells followed by several biochemical tests has been developed for this purpose.

\section{Observations}

Identification of bacterial strains: So far our observation is taken into consideration the following types of microorganisms have been isolated from the meat and chicken samples and are mention in the following Table 1 .

\section{Antimicrobial susceptibility testing}

Antimicrobial activity of various chemical substances against various isolated bacterial strains from chicken and mutt on samples (Tables 2-8).

\section{Results and Discussion}

Altogether 06 bacterial isolates were obtained from chicken

\begin{tabular}{|l|c|c|c|c|}
\hline \multirow{3}{*}{ S. No } & \multicolumn{4}{|c|}{ Name of Bacteria Isolated } \\
\cline { 2 - 5 } & \multicolumn{2}{|c|}{ Chicken Sample } & \multicolumn{2}{c|}{ Mutton Sample } \\
\cline { 2 - 5 } & Halal & Jatka & Halal & Jatka \\
\hline & Shigella & -------------- & ------- & Shigella \\
\hline & $\begin{array}{c}\text { Enterobacter } \\
\text { species }\end{array}$ & $\begin{array}{c}\text { Enterobacter } \\
\text { species }\end{array}$ & - & ------------ \\
\hline & Clostridium & Clostridium & ------------- & ------------- \\
\hline & E. coli & E. coli & E. coli & E. coli \\
\hline & Vibrio & --------- & Vibrio & Vibrio \\
\hline & --------- & -------- & Staphylococcus & Staphylococcus \\
\hline
\end{tabular}

Table 1: Showing various bacterial strains isolated from the chicken and mutton samples.

\begin{tabular}{|l|c|c|c|}
\hline S. No & Strain Used & Chemical Used & Zone of Inhibition (mm) \\
\hline 1 & Shigella & Gentamicin & 29 \\
\hline 2 & Shigella & Naphthazarin & 19 \\
\hline 3 & Shigella & Azithromycin & 6 \\
\hline 4 & Shigella & Citric Acid & 27 \\
\hline 5 & Shigella & Amphotericin-B & Nil \\
\hline 6 & Shigella & Clindomycin & 10 \\
\hline 7 & Shigella & Cefixime & Nil \\
\hline 8 & Shigella & Norfloxacin & 18 \\
\hline 9 & Shigella & Streptomycin & 17 \\
\hline 10 & Shigella & Ampicilin & 13 \\
\hline
\end{tabular}

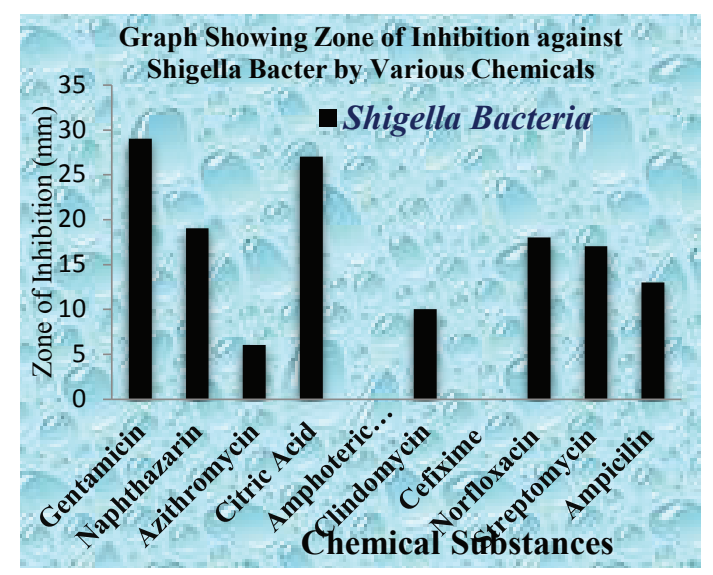

Table 2: Inhibition against Shigella Bacter by Various Chemicals.

\begin{tabular}{|c|c|c|c|}
\hline S. No & Strain Used & Chemical Used & Zone of Inhibition (mm) \\
\hline 1 & E. coli & Gentamicin & 28 \\
\hline 2 & E. coli & Naphthazarin & 15 \\
\hline 3 & E. coli & Azithromycin & 06 \\
\hline 4 & E. coli & Citric Acid & 26 \\
\hline 5 & E. coli & Amphotericin-B & Nil \\
\hline 6 & E. coli & Clindomycin & Nil \\
\hline 7 & E. coli & Cefixime & Nil \\
\hline 8 & E. coli & Norfloxacin & 18 \\
\hline 9 & E. coli & Streptomycin & 17 \\
\hline 10 & E. coli & Ampicilin & 13 \\
\hline
\end{tabular}

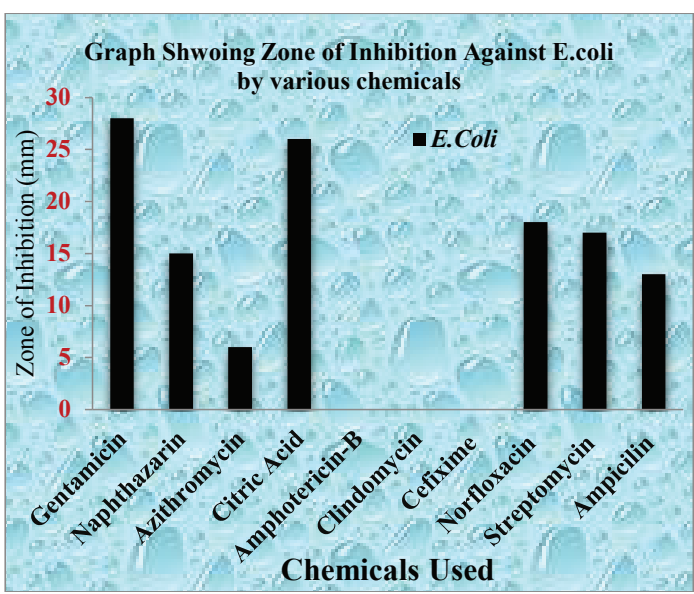

Table 3: Inhibition Against E. coli by various chemicals.

\begin{tabular}{|l|c|c|c|}
\hline S. No & Strain Used & Chemical Used & Zone of Inhibition (mm) \\
\hline 1 & Vibrio & Gentamicin & 30 \\
\hline 2 & Vibrio & Naphthazarin & 16 \\
\hline 3 & Vibrio & Azithromycin & Nil \\
\hline 4 & Vibrio & Citric Acid & 25 \\
\hline 5 & Vibrio & Amphotericin-B & Nil \\
\hline 6 & Vibrio & Clindomycin & Nil \\
\hline 7 & Vibrio & Cefixime & Nil \\
\hline 8 & Vibrio & Norfloxacin & Nil \\
\hline 9 & Vibrio & Streptomycin & 15 \\
\hline 10 & Vibrio & Ampicilin & Nil \\
\hline
\end{tabular}

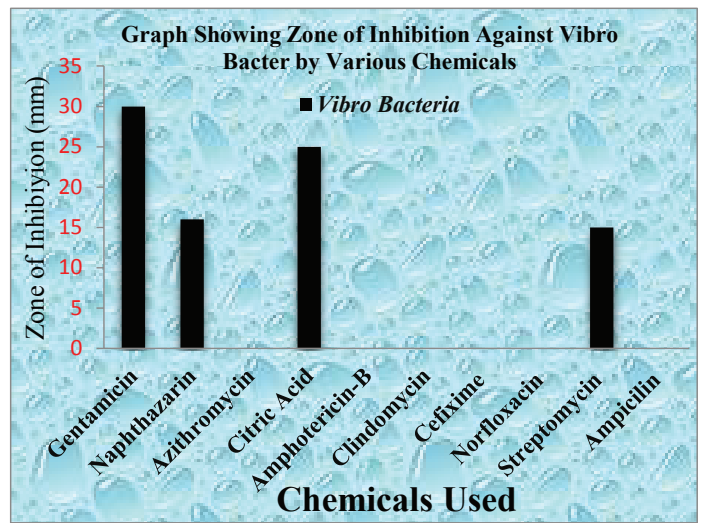

Table 4: Inhibition Against Vibro Bacter by Various Chemicals.

sample and 04 isolates from mutton sample. The bacterial isolates were screened for their thermo-tolerance property in different temperatures starting from $50^{\circ} \mathrm{C}$ to $90^{\circ} \mathrm{C}$.

The bacterium Staphylococcus species is a spherical bacterium 
Citation: Ahmad Mir B, Mir A, Singh D, Rao Z (2017) Evaluation of Antimicrobial Activity of Various Chemicals on Isolated Chicken and Mutton Spoilage Microorganisms. Med Chem (Los Angeles) 7: 900-903. doi: 10.4172/2161-0444.1000450

\begin{tabular}{|l|c|c|c|}
\hline S. No & Strain Used & Chemical Used & Zone of Inhibition (mm) \\
\hline 1 & Enterobacter Species & Gentamicin & 27 \\
\hline 2 & Enterobacter Species & Naphthazarin & 20 \\
\hline 3 & Enterobacter Species & Azithromycin & Nil \\
\hline 4 & Enterobacter Species & Citric Acid & 24 \\
\hline 5 & Enterobacter Species & Amphotericin-B & Nil \\
\hline 6 & Enterobacter Species & Clindomycin & 13 \\
\hline 7 & Enterobacter Species & Cefixime & Nil \\
\hline 8 & Enterobacter Species & Norfloxacin & Nil \\
\hline 9 & Enterobacter Species & Streptomycin & 15 \\
\hline 10 & Enterobacter Species & Ampicilin & Nil \\
\hline
\end{tabular}

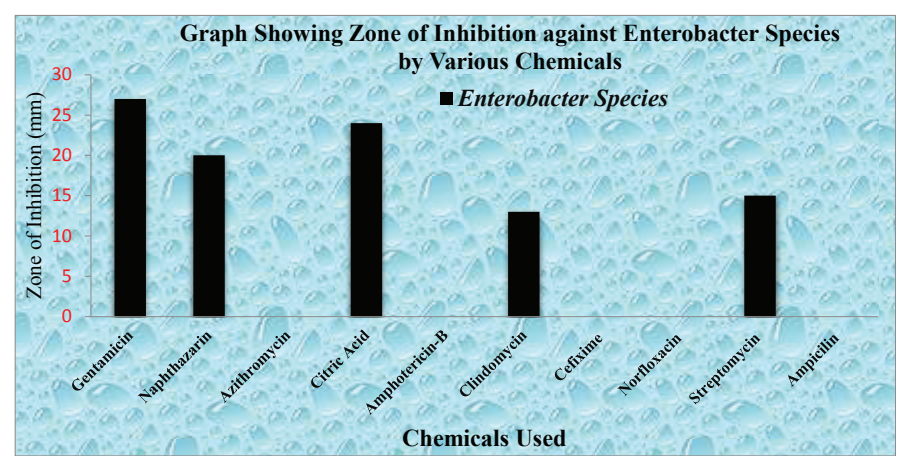

Table 5: Inhibition against Enterobacter Species by Various Chemicals.

\begin{tabular}{|l|c|c|c|}
\hline S. No & Strain Used & Chemical Used & Zone of Inhibition (mm) \\
\hline 1 & Clostridium & Gentamicin & 27 \\
\hline 2 & Clostridium & Naphthazarin & 17 \\
\hline 3 & Clostridium & Azithromycin & 14 \\
\hline 4 & Clostridium & Citric Acid & 25 \\
\hline 5 & Clostridium & Amphotericin-B & Nil \\
\hline 6 & Clostridium & Clindomycin & 19 \\
\hline 7 & Clostridium & Cefixime & Nil \\
\hline 8 & Clostridium & Norfloxacin & 20 \\
\hline 9 & Clostridium & Streptomycin & 12 \\
\hline 10 & Clostridium & Ampicilin & 10 \\
\hline
\end{tabular}

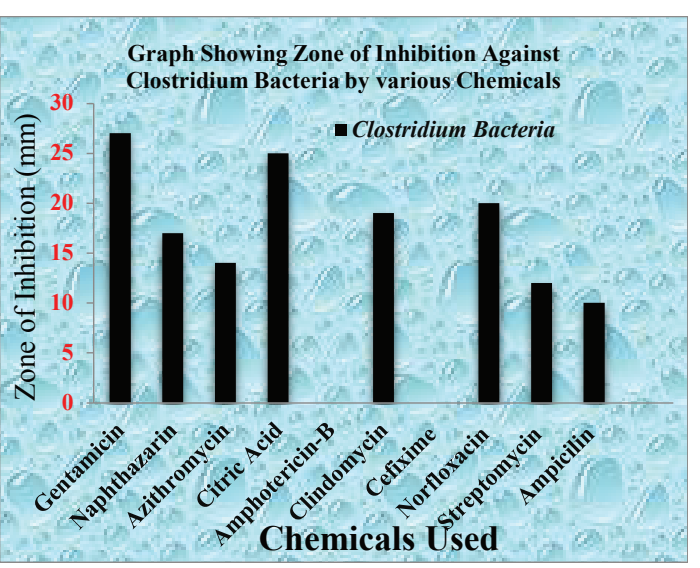

Table 6: Inhibition against Clostridium Bacteria by various Chemicals.

(coccus) which on microscopic examination appears singly, in pairs, or bunched, grape-like clusters. They are Gram-positive, facultative anaerobes, but grow rapidly under aerobic conditions and were characterized by morphological observation and biochemical tests. Salmonella is a rod-shaped, Gram negative, non-sporulating, facultative anaerobic motile bacterium. They are mesophiles with a growth temperature range of 5 to $46^{\circ} \mathrm{C}$ and optimum growth temperature of 35

\begin{tabular}{|l|c|c|c|}
\hline S. No & Strain Used & Chemical Used & Zone of Inhibition (mm) \\
\hline 1 & Staphylococcus & Gentamicin & 24 \\
\hline 2 & Staphylococcus & Naphthazarin & 17 \\
\hline 3 & Staphylococcus & Azithromycin & Nil \\
\hline 4 & Staphylococcus & Citric Acid & 22 \\
\hline 5 & Staphylococcus & Amphotericin-B & Nil \\
\hline 6 & Staphylococcus & Clindomycin & 11 \\
\hline 7 & Staphylococcus & Cefixime & $\mathrm{Nil}$ \\
\hline 8 & Staphylococcus & Norfloxacin & $\mathrm{Nil}$ \\
\hline 9 & Staphylococcus & Streptomycin & 13 \\
\hline 10 & Staphylococcus & Ampicilin & $\mathrm{Nil}$ \\
\hline
\end{tabular}

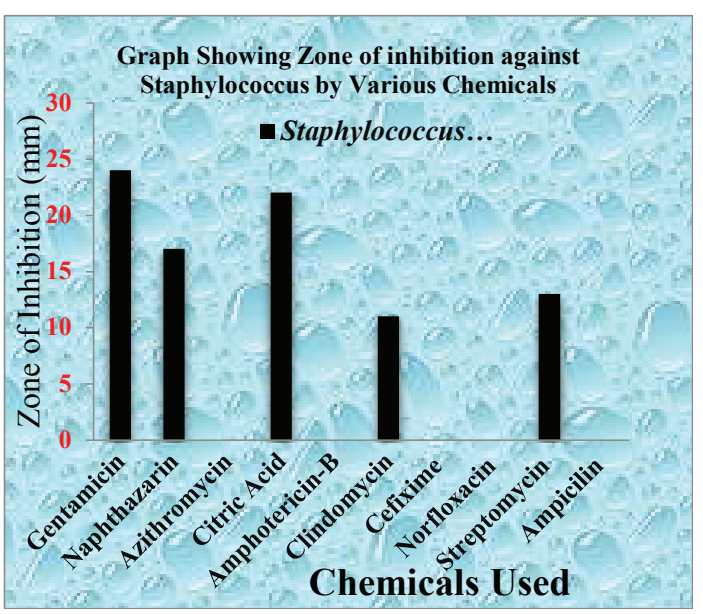

Table 7: Inhibition against Staphylococcus by Various Chemicals.

\begin{tabular}{|l|c|c|c|}
\hline S. No & Strain Used & Chemical Used & Zone of Inhibition $\mathbf{( m m})$ \\
\hline 1 & Salmonella & Gentamicin & 27 \\
\hline 2 & Salmonella & Naphthazarin & 16 \\
\hline 3 & Salmonella & Azithromycin & Nil \\
\hline 4 & Salmonella & Citric Acid & 27 \\
\hline 5 & Salmonella & Amphotericin-B & Nil \\
\hline 6 & Salmonella & Clindomycin & Nil \\
\hline 7 & Salmonella & Cefixime & Nil \\
\hline 8 & Salmonella & Norfloxacin & Nil \\
\hline 9 & Salmonella & Streptomycin & 15 \\
\hline 10 & Salmonella & Ampicilin & Nil \\
\hline
\end{tabular}

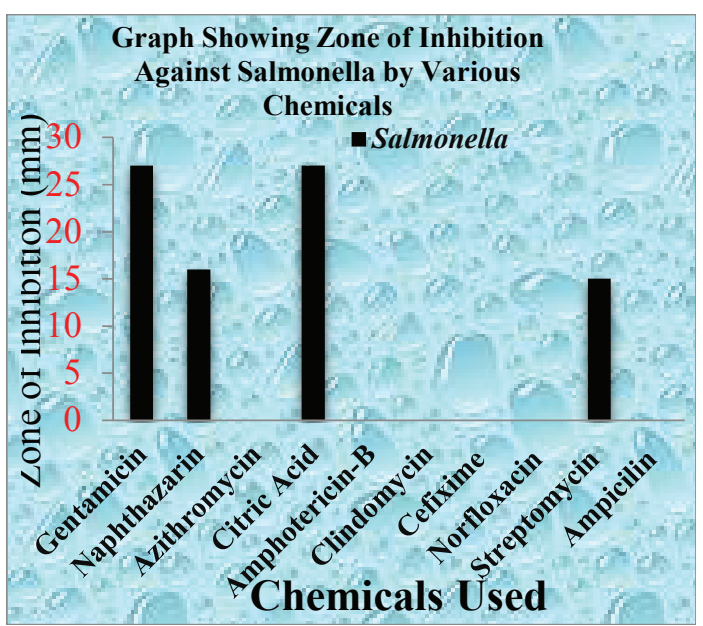

Table 8: Inhibition Against Salmonella by Various Chemicals.

to $37^{\circ} \mathrm{C}$. Litmus milk test, Gelatin Agar test and Urea agar media viable cells followed by several biochemical tests lead to the identification of 
Salmonella. Shigella was identified as Gram-negative, non-motile, nonspore forming rod-shaped bacteria as per Litmus milk test, Gelatin Agar test and Urea agar media followed by several biochemical tests. The strains grow between 7 and $46^{\circ} \mathrm{C}$, with an optimum at $37^{\circ} \mathrm{C}$. Litmus milk test, Gelatin Agar test and Urea agar media followed by several biochemical tests identified E. coli as harmless, Gram negative, motile, non-sporulating; rod shaped facultative anaerobic bacterium. Vibrio bacterium as identified as Gram-negative, non-sporulating motile curved rods with an optimum temperature of $30^{\circ} \mathrm{C}$ to $37^{\circ} \mathrm{C}$, but can grow over a temperature range of 5 and $42^{\circ} \mathrm{C}$ as per Gelatin Agar test and Urea agar media followed by several biochemical tests. The identification of Enterobacter bacteria was carried out by Gelatin Agar test and Urea agar media followed by several biochemical tests and had been identified as motile, rod-shaped cells, some of which are encapsulated. Clostridium was identified as an anaerobic, Grampositive, spore-forming rod that produces a potent neurotoxin by various tests like Gelatin Agar test and Urea agar media followed by several biochemical tests.

Preliminary Screening for the anti-bacterial activity was performed using Agar Well diffusion method. The mentioned Chemical substances showed an excellent antibacterial activity against the bacteria Shigella, Enterobacter species, Clostridium, E. coli, Vibrio, and Staphylococcus. As per the microbial susceptibility tests Gentamicin showed highest antibacterial activity against Shigella bacterium fallowed by citric acid, Naphthazarin, Norfloxacin, Streptomycin and less activity was observed for Azithromycin. Gentamicin showed highest antimicrobial activity against E. coli, followed by citric acid, Norfloxacin, Streptomycin and Naphthazarin. Least activity was observed by azithromycin antibiotic. For Vibrio bacterium, the highest zone of inhibition was showed by Gentamicin fallowed by citric acid, Naphthazarin and less activity was observed for streptomycin. Clindomycin, Azithromycin, Amphotericin-B, Cefixime, Norfloxacin, and Ampicilin showed no any activity against Vibrio Bacterium. Enterobacter species have no any effect upon the utilization of Azithromycin, Amphotericin-B, Cefixime, Norfloxacin, and Ampicilin. The concerned bacterium is adducted against these antibiotics. Gentamicin have a highest response against Enterobacter as per antimicrobial susceptibility is taken into consideration followed by citric acid, Naphthazarin and Clindomycin. Clostridium bacteria have no any effect against antibiotics like Cefixime, and Amphotericin-B. Ampicilin have less activity against Clostridium bacteria and highest antimicrobial susceptibility was observed for Gentamicin followed by citric acid Norfloxacin, Clindomycin, Naphthazarin, Azithromycin, Streptomycin. The Highest Zone of Inhibition was observed by Gentamicin against Staphylococcus, followed by Citric Acid, Naphthazarin, Streptomycin and Clindomycin. No any activity was observed by the use of Azithromycin, Amphotericin-B, Cefixime, Norfloxacin and Ampicilin antibiotics. Salmonella bacterium a strong bacteria and some antibiotics like Gentamicin, Naphthazarin and citric acid have some antimicrobial activity against salmonella. Rest of the used antibiotics like, Ampicilin, Norfloxacin, Cefixime, Amphotericin-B and azithromycin have no any activity against the salmonella bacterium.

\section{Conclusion}

From the above mention research it could be concluded that the spoiled chicken and mutton samples should not be consumed. Being rich in protein content the chicken and the mutton samples are frequently affected by various bacterial strains. Also from the collected chicken and mutton samples the samples of Halal type have been found to be less effective against the growth of micro-organisms as compared to the Jatka type samples, which could be due to different procedure of slaughtering technique. In case of Jatka the animal is being slaughtered at once and the blood gets coagulated within no time, but during the slaughtering process in which the animal is being slaughtered in a Halal way, makes whole blood to come out of the body of an animal. So as per this research it could be concluded that Halal type of flesh should be consumed than the Jatka type.

\section{References}

1. Stadnik J, Dolatowski Z (2010) Biogenic amines in meat and fermented meat products. ACTA Scientiarum Polonorum Technologia Alimentaria 9: 251-263.

2. Nychas GJ, Skandamis PN, Tassou CC, Koutsoumanis KP (2008) Meat spoilage during distribution. Meat Science 78: 77-89.

3. Svobodová I, Bořilová G, Hulánková R, Steinhauserová I (2012) Microbiological quality of broiler carcasses during slaughter processing. Acta Veterinaria Brno 81: $37-42$.

4. White PL, Baker AR, James WO (1997) Strategies to control Salmonella and Campylobacter in raw poultry products. Revue Scientifique et Technique 16: 525-541.

5. Stadnik J, Dolatowski J (2010) Biogenic amines in meat and fermented meat products. ACTA Scientiarum Polonorum Technologia Alimentaria 9: 251-263. 